Jpn. J. Oral Biol., $40: 506-514,1998$.

\title{
ORIGINAL
}

\section{Generation of duplication or deletion mutants in Streptococcus mutans following homologous recombination-mediated random mutagenesis by integrational vector pVA891}

\author{
Yutaka Sato,**, Yasuhito Yamamoto** and Harutoshi Kizaki*,** \\ Oral Health Science Center*, Department of Biochemistry**, Tokyo Dental College \\ (Chief : Prof. Harutoshi Kizaki) \\ 2-2, Masago 1-chome, Mihama-ku, Chiba City 261-8502, Japan \\ 〔Received on June 17, 1998 ; Accepted on August 3, 1998〕
}

Key words : $S$. mutans/chromosomal rearrangement/merodiploidy/Campbell-like mechanism/integration vector /glucan-binding protein

\begin{abstract}
Integration vectors have been used as genetic tools for mutagenesis in a number of organisms. We introduced random mutation into Streptococcus mutans with one of the vectors pVA891, and screened the mutants for the glucan-dependent aggregation-negative phenotype to isolate the genes involved in this property. Insertion of pVA891 containing a Sau3AI-digested host DNA fragment into the chromosome occurs following homologous recombination via a Campbell-like mechanism. This type of integration should generate a direct repeat of the homologous region at both ends of inserted pVA891. However, most mutants that we obtained do not have such a duplication and appear to have resulted from chromosomal rearrangements. For instance, the $g b p C$ gene encoding the cell-bound glucan-binding protein was identified in the region deleted from the chromosome in one mutant. Several dozen other mutants exhibiting the nonaggregation phenotype harbored the intact $g b p C$ gene and were shown to be diploid for large chromosomal regions. Based on the analysis of the chromosome from the duplication mutants, we propose that these deletions and duplications were generated by an unequal cross-over between two pVA891 sequences following multiple integrations of the vectors by a Campbell-like mechanism.
\end{abstract}

抄録：多くの細菌においてインテグレーションベクターは遺伝子操作ツールとして使われてきている。われわ れはそのべクターの 1 つである pVA891 を用いて S. mutans にランダム変異導入し, この菌のグルカン依存性凝 集に関与する遺伝子をクローニングするため,この凝集を起こさない変異株を分離してきた。Sau3AI で完全消化 したホスト DNA フラグメントを含むpVA891 のホスト染色体への挿入は, キャンベル様機構による相同組換え により起こる。このタイプのプラスミッドインテグレーションは，挿入された pVA891 の両端に組換えを起こし た相同領域の反復配列が生じるはずである。しかし，われわれの分離した変異株の多くはそのような反復配列を 持っておらず，染色体の再配列が起きているようであった。その1例として，われわれがすでにクローニングし た細胞結合性グルカン結合蛋白質をコードしている $g b p C$ 遺伝子は，それらの変異株の 1 つにおける欠失染色体 領域で同定された。一方，他の多数のグルカン依存性凝集を示さない変異株はインタクトな $g b p C$ 遺伝子を保持 しており，染色体のかなり大きな領域に部分重複が認められた。それらの部分重複変異株の染色体の解析に基づ き, それらの変異株における欠失や重複はキャンベル様機構による複数の pVA891 のインテグレーション後, そ れら 2 つのべクター塩基配列を介した不等交叉により生じたものであると，われわれは提起する。 


\section{Introduction}

Integrative plasmid vectors can mutagenize host chromosomes by a homologous recombinationmediated Campbell-like insertion. This method was developed in the early 1980 's, extensively investigated in bacilli ${ }^{1,2)}$, and has been applied to several genera, including Streptococcus ${ }^{3 \sim 5)}$, Porphyromonas ${ }^{6)}$, and Campylobacter ${ }^{7}$, as a powerful technique for identify. ing and characterizing genes of interest. The integrative plasmids have proven to be useful tools in genetic engineering of organisms, especially those for which transposon mutagenesis is difficult or not avail$a^{2} e^{7)}$. Moreover, an integrated vector is easily recovered in Escherichia coli with DNA flanking the insertion because the vector has a replicon and a selectable marker (e.g. antibiotics resistance gene) able to function in $E$. coli. The vectors must have other properties essential for integration into the target host chromosome as previously described ${ }^{2)}$ : (i ) They do not have replication origin functioning in the host organism but do have selectable marker functioning in the host. (ii) They contain a chromosomally derived host DNA segment used for homologous recombination to establish integration into the host chromosome. When the segment is a specific DNA fragment, targeted insertion occurs while chromosomally derived heterologous segments lead to random integration of the vector ${ }^{7}$. In both cases, if the segment is internal to a gene or an operon, the insertion is mutagenic. This integration is thought to occur by a Campbell-like mechanism and it generates a direct repeat of the DNA segment.

We have applied this method for random mutagenesis in Streptococcus mutans, which is involved in human dental caries, and have identified several genes ${ }^{3 \sim 5)}$. However, following mutagenesis, we also isolated many mutants whose properties cannot be explained by a typical Campbell-like mechanism. Deletions or duplications were observed in regions flanking the insertion. Based on an extensive analysis of chromosomal DNA from these mutants, we propose a possible mechanism for the occurrence of deletion or duplication mutants in $S$. mutans following homologous recombination-mediated vector integration.

\section{Materials and Methods}

\section{Microorganisms}

S. mutans clinical isolate $109 \mathrm{c}$ and its spontaneous colonization defective strain $109 \mathrm{cS}$ were used. Both strains retain a glucan-dependent aggregation trait, $\operatorname{ddag}^{+5)}$. E. coli strains HB101 and JM109 were maintained and grown routinely as previously described ${ }^{5)}$.

\section{Preparation of DNA in agarose blocks}

Chromosomal DNA from $S$. mutans was prepared as described by Okahashi et al ${ }^{8)}$ with little modification. $1.0 \mathrm{ml}$ of an overnight culture was diluted into $4.0 \mathrm{ml}$ of Todd-Hewitt broth (Difco), grown to an O.D. $660 \mathrm{~nm}$ of approximately 0.7 and incubated for an additional hour supplemented with $0.5 \mathrm{~g}$ of glycine. The cells were washed with $10 \mathrm{mM}-\mathrm{TrisCl}$ ( $\mathrm{pH} 8.0$ ) containing $1 \mathrm{M} \mathrm{NaCl}$, and suspended in 1.0 $\mathrm{m} l$ of the same buffer. The suspension was then mixed with $1.0 \mathrm{ml}$ of $1 \%$ InCert agarose (FMC), and $90 \mu l$ each of the mixture was allowed to solidify in a commercially supplied mould to form blocks. The agarose blocks were successively treated with a lysis solution, proteinase $\mathrm{K}$ solution, and $1 \mathrm{mM}$ phenylmethylsulphonyl fluoride, and washed as described previously $^{8)}$.

\section{Restriction enzyme digestion}

The DNA agarose blocks were incubated overnight at $37^{\circ} \mathrm{C}$ with 30 to 60 units of $A p a \mathrm{I}$, or Not I (Toyobo) in a total volume of $500 \mu l$.

\section{Pulse field gel electrophoresis}

CHEF system (CHEF-DR II, Bio-Rad) with $1 \%$ $(\mathrm{W} / \mathrm{V})$ agarose (SeaKem GTG) in $0.5 \times \mathrm{TBE}$ buffer at $16^{\circ} \mathrm{C}$ was used. Gels were run at $200 \mathrm{~V}$ for $24 \mathrm{~h}$ with pulse times ranging from 0.2 to $20 \mathrm{~s}$.

\section{Southern hybridization analysis}

Restriction enzyme-digested chromosomal DNA fragments from mutants and their parental strain 
were separated following agarose mini-gel electrophoresis or pulse field (CHEF) gel electrophoresis and transferred to nylon membrane (Nytran, S \& S) as previously described ${ }^{9}$. The fragments were analyzed by ECL direct nucleic acid labelling and detection system as recommended by the supplier (Amersham).

\section{Preparation of DNA fragments for probes}

Following Southern hybridization analysis of chromosomal DNA of the mutants probed with a linearized pVA891 fragment, chromosomal DNA from the mutants was isolated, digested with EcoRI or Hind III to generate fragments containing pVA891, and self-ligated. $E$. coli $\mathrm{HB} 101$ competent cells were then transformed with the ligation mixtures, and plasmids with flanking regions were recovered as previously described ${ }^{5}$. The flanking chromosomal fragments were isolated following restriction digestion and separation with agarose mini-gel electrophoresis.

\section{Results}

We recently isolated glucan-dependent aggregation-negative mutants of $S$. mutans $109 \mathrm{cS}$ following random mutagenesis using integrational vector
pVA891 as described previously5). A chromosomal region responsible for this phenotype was characterized in one of the mutants, and the responsible gene, $g b p C$ encoding a cell surface glucan-binding protein, was identified. Besides this mutant, we have isolated glucan-aggregation negative mutants in which the $g b p C$ gene appeared intact when analyzed by South ern hybridization. Since regulatory genes for the $g b p C$ gene were thought to be mutated in these mutants, we further characterized some of these mutants in order to identify the affected genes.

Chromosomal DNA fragments from 10 aggregation negative mutants and their parental strain $109 \mathrm{cS}$ were separated following agarose mini-gel electrophoresis, and analyzed by Southern hybridization. Blots of EcoRI- or Hind III-digested chromosomal DNA from the 10 mutants probed with a linearized pVA891 fragment displayed different patterns (data not shown). This indicated that the vector pVA891 was randomly inserted into distinct positions on the chromosome in all 10 mutants. We then analyzed the blot of EcoRIdigested chromosomal DNA probing with DNA fragments containing chromosomal regions flanking each side of the insertion in one mutant 25G11. We designate these fragments $A$ and $B$ with subscripts for their origin $\left(A_{25 G 11}\right.$ and $\left.B_{25 G 11}\right)$ (Fig. 1). These two frag-
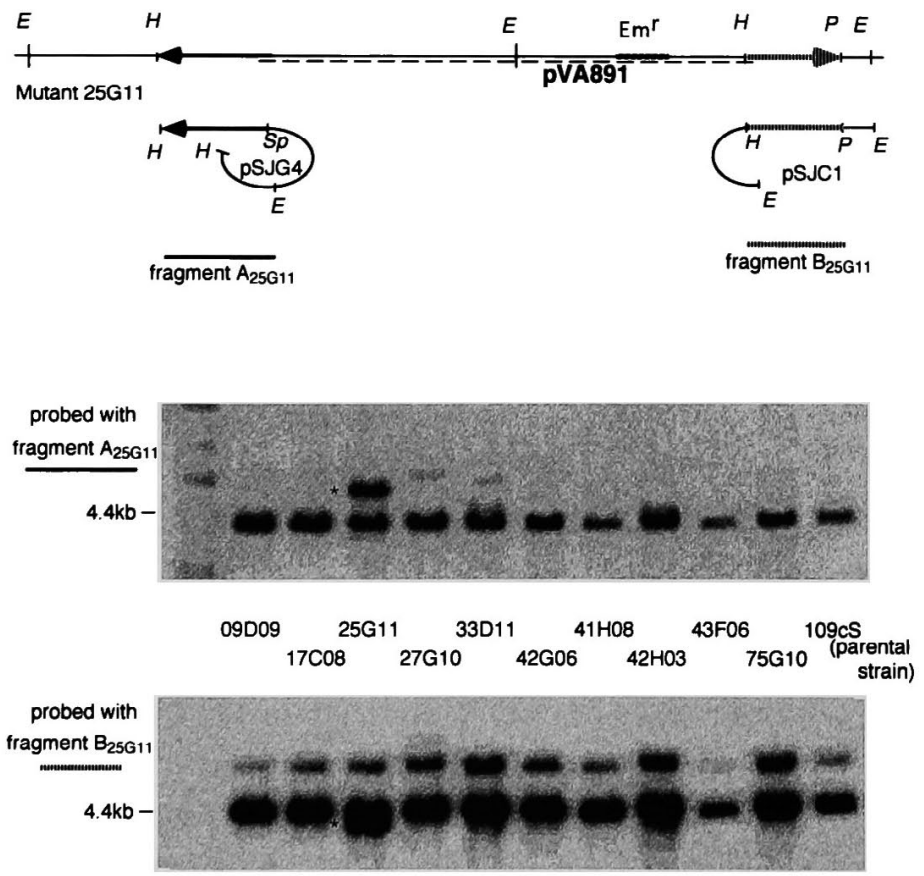

Fig. 1 Restriction map of the pVA891 inserted region of chromosomal DNA in mutant $25 \mathrm{G} 11$ and the rescued plasmids (pSJG4 and $\mathrm{pSJCl}$ ) containing the fragments used for the Southern blot analysis.

The blot of the EcoRI-digested chromosomal DNA from the 10 mutants and their parental strain $109 \mathrm{cS}$ separated following agarose mini-gel electrophoresis was analyzed with the DNA fragments $A_{25 \mathrm{G}_{11}}$ or $B_{25 G 11}$ as probes. These two fragments were isolated from the two plasmids (pSJG4 and pSJC1) respectively rescued in $E$. coli as described in the text. Duplicated bands in the lane for 25G11 are marked with an asterisk. Other symbols are : $\mathrm{Em}^{\mathrm{r}}$, the erythromycin resistance gene ; $E, E c o \mathrm{RI} ; H$, Hind III : $P, P s t$ I ; Sp, Sph I 
ments were isolated respectively from the two plasmids rescued into $E$. coli following digestion of the 25G11 chromosomal DNA with EcoR I or Hind III (pSJC1 and pSJG4 in Fig. 1.) as described in Materials and Methods. When analyzed using either fragment $A_{25 G 11}$ or $B_{25 G 11}$ as a probe, a positive band of the same size as that detected for parental chromosomal DNA was detected in all lanes including 25G11 lane. Surprisingly, this indicated that a host chromosomal region generated by homologous recombination remained intact in 25G11. Additionally, a distinct size band (asterisk in Fig. 1.) was detected only for 25G11 with either probe, indicating that both fragments flanking the insertion were duplicated in mutant 25G11. Moreover, a band in common to all lanes probed with fragment $A_{25 G 11}$ was slightly different in size from that probed with fragment $B_{25 G 11}$ indicating that fragment $A_{25 G 11}$ and $B_{25611}$ were located at distinct loci on the chromosome of the parental strain. (However in the vector-integrated region in 25G11 fragments $A_{25 G 11}$ and $B_{25 G 11}$ were located adjacent to the integrated vector pVA891). When analysis was carried with the fragments $A_{27 G 10}$ and $B_{27 G 10}$ which were derived from another mutant $27 \mathrm{G} 10$, duplicated positive bands were detected only in 27G10 (data not shown). For this mutant, one positive band was detected in all lanes of the same size as that detected in the lane for parental strain $109 \mathrm{cS}$. Besides mutants $25 \mathrm{G} 11$ and $27 \mathrm{G} 10$, we analyzed several other mutants and our findings were identical in all respects (apparent duplication of flanking regions). These findings suggested that all of these mutants contained partially duplicated chromosomal regions of various sizes and at different loci on the chromosome. These findings also suggest that fragments $\mathrm{A}$ and $\mathrm{B}$ which were originally located at distinct loci on the chromosome of the parental strain were duplicated and rearranged adjacent to the plasmid insertion site in all mutants presumably by a specific common mechanism.

Figure 1 indicates that all the mutants we analyzed were generated by a common mechanism. To elucidate this mechanism, we employed pulse field (CHEF) gel electrophoresis following restriction digestion of the chromosomal DNA from the mutants with the rare-cutting restriction enzymes Not I or
$A p a \mathrm{I}$. The restriction enzyme Not I digested the chromosomal DNA from $109 \mathrm{cS}$ and $25 \mathrm{G} 11$ into 7 fragments ranging from $20 \mathrm{~kb}$ to more than $1,000 \mathrm{~kb}$ (> $1,000 \mathrm{~kb}$ ), and both fragments $A_{25 G 11}$ and $B_{25 G 11}$ hybridized with the $>1,000 \mathrm{~kb}$ fragments of the mutant and parental strains. In contrast, the restriction enzyme $A p a$ I digested DNA into about 20 fragments with several duplicated bands ranging from 15 to $340 \mathrm{~kb}$, and both probes hybridized with a $135 \mathrm{~kb}$ fragment of $109 \mathrm{cS}$ and a $195 \mathrm{~kb}$ fragment of 25G11 (see Fig. 2 panels $A$ and $C$, lanes 1 and 4 ). The integration plasmid pVA891 also hybridized with the $195 \mathrm{~kb}$ fragment in 25G11 (data not shown). This $195 \mathrm{~kb}$ fragmant was not detected in $109 \mathrm{cS}$, while the $135 \mathrm{~kb}$ band of $109 \mathrm{cS}$ was absent in 25G11 (Fig. 2 panel B, lanes 1 and 4). These findings suggest that the original $135 \mathrm{~kb}$ fragment present in $109 \mathrm{cS}$ was partially duplicated by a rearrangement following pVA891 integration which resulted in the $195 \mathrm{~kb}$ fragment in 25G11. Similar analyses using the fragments flanking the plasmid insertion (e.g. $\mathrm{A}_{27 \mathrm{G}_{10}}$ and $\mathrm{B}_{27 \mathrm{G}_{10}}$ etc.) in other mutants suggested that partially duplicated chromosomal regions in other mutants were much larger than in 25G11. Therefore, we further attempted to identify the location and relative orientation of the two fragments $A_{25 G 11}$ and $B_{25 G 11}$, as outlined in Figure 3.

We constructed an additional two integration plasmids (plasmids $\mathrm{A}$ and $\mathrm{B}$ in Fig. 3) containing Apa I sites and either fragment $A_{25 G 11}$ or $B_{25 G 11}$. Transformation of $109 \mathrm{cS}$ with plasmid $\mathrm{A}$ or $\mathrm{B}$ by a Campbell-like integration resulted in the isolation of integrants SIV96 or SH791, respectively, in which the chromosomal duplication of either $\mathrm{A}_{25 \mathrm{G} 11}$ or $\mathrm{B}_{25 \mathrm{G} 11}$ moiety having the "artificial" $A p a$ I site could occur. Since the location of the $A p a \mathrm{I}$ site relative to the DNA fragment $A_{25 G 11}$ or $B_{25 G 11}$ in integration plasmid A or B was known, Southern blotting of chromosomal Apa I digests from both integrants SIV96 or SH791 probed with the vector sequence of plasmid A or B allowed us to determine the relative location and orientation of the two fragments $\mathrm{A}_{25 \mathrm{G}_{11}}$ or $\mathrm{B}_{25 \mathrm{G} 11}$ in the parental strain $109 \mathrm{cS}$.

As shown in Fig. 2, panel B, ethidium bromide staining of the CHEF gel indicated that fragments corresponding to the $135 \mathrm{~kb}$ fragment of $109 \mathrm{cS}$ were dis- 


\section{A.}

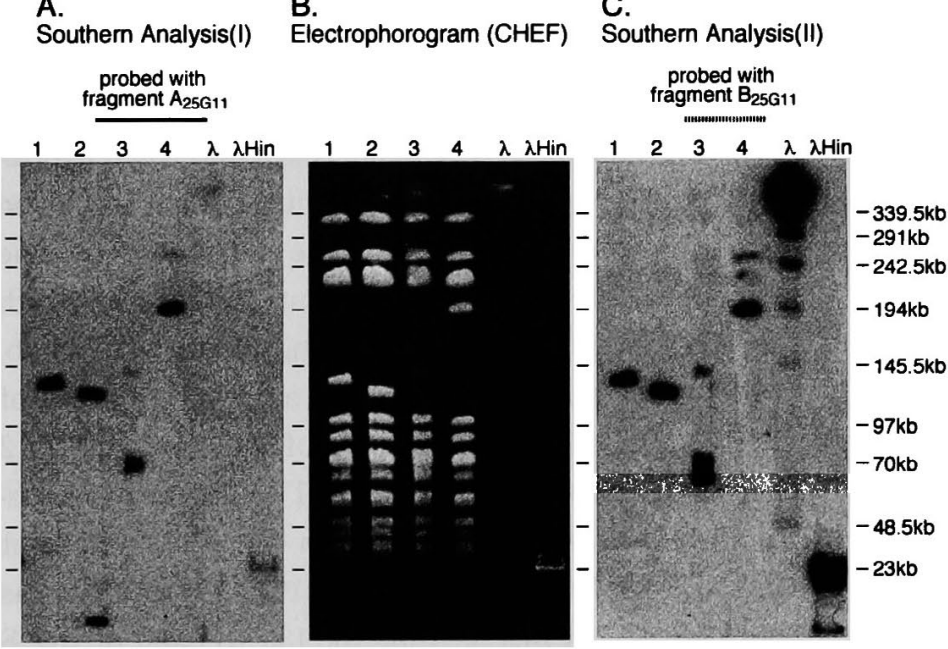

Fig. 2 Results of pulse field (CHEF) gel electrophoresis and its Southern hybridization analysis for identification of the original location and orientation of fragments $\mathrm{A}_{25 \mathrm{G1}}$ and $\mathrm{B}_{25 \mathrm{G} 11}$ on the chromosome of the parental strain $109 \mathrm{cS}$.

Apa I digested chromosomal DNA from $109 \mathrm{cS}$, SIV96, SH791, and 25G11 were separated with the CHEF system, transferred to a nylon membrane, and analyzed with either fragments $A_{25 G 11}$ or $\mathrm{B}_{25 \mathrm{G1}}$ as probes. SIV96 and SH791 are integrants of plasmid A and B respectively (see Fig. 3).

Lanes 1, 109cS ; 2, SIV96 ; 3, SH791 ; 4, 25G11；5, $\lambda$ ladder marker $; 6, \lambda$ Hind III digest.

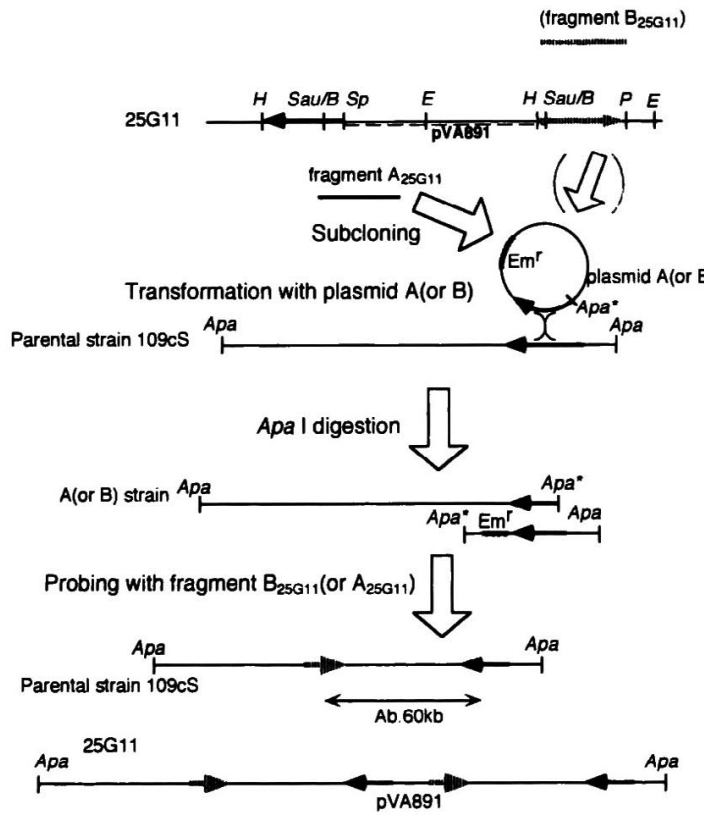

(Fragment A and B were drawn larger than actual for explanation in the figure)
Line

1.

2.

3.

Fig. 3 Strategy to identify the original location and orientation of fragments $A_{25 G 11}$ and $B_{25 G 11}$ on the chromosome of the parental strain $109 \mathrm{cS}$.

4. Plasmid A (or B) containing an $A p a$ I site was constructed and then integrated to introduce the Apa I site simultaneously into the chromosome of $109 \mathrm{cS}$. When Southern blot analysis of the resultant mutants was performed with fragments $B_{25 G i 1}$ (or $A_{25 G_{11}}$ ) as probes, their location and orientation could be identified. Other symbols are: $\mathrm{Em}^{\mathrm{r}}$, the erythromycin resistance gene : $A p a, A p a$ I : $A p a^{*}$, "artificial" Apa I sites.

tion of the fragment $A_{25 G 11}$. When the membrane was reprobed with the fragment $B_{25 G 11}$, a $125 \mathrm{~kb}$ band was solely recognized in SIV96 (panel C, lane 2), and both $70 \mathrm{~kb}$ and $65 \mathrm{~kb}$ positive bands were visualized in SH791 (lane 3). The membrane was further reprobed with the vector sequence of plasmids $\mathrm{A}$ and $\mathrm{B}$ to assess the relative orientation of the two fragments (data not shown). By combining the results of all played as $125 \mathrm{~kb}$ and $10 \mathrm{~kb}$ fragments in SIV96, and as $70 \mathrm{~kb}$ and $65 \mathrm{~kb}$ bands in SH791 (Fig. 2, panel B, lanes 1,2 and 3 ). However, the bands in the latter were not clear because of overlaps with other bands. When the blotted membrane was probed with the fragment $A_{25 G 11}$, a sole $70 \mathrm{~kb}$ fragment was developed in SH791 (panel A, lane 3), and $125 \mathrm{~kb}$ and $10 \mathrm{~kb}$ frag. ments appeared in SIV96 (lane 2) due to the duplica- 


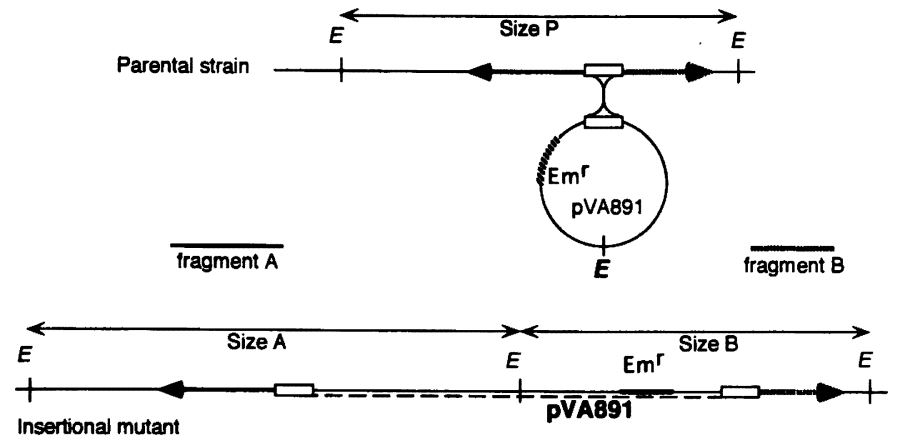

Fig. 4 Schematic illustrations of a typical Campbelltype integration.

Open boxes represent homologous regions and the tandem repeat unit generated by a typical Campbelltype integration.
Southern blot analyses, we successfully determined the location and orientation of the two fragments $A_{25 G 11}$ or $B_{25 G 11}$ in $109 \mathrm{cS}$ as shown in Figure 3, line 4.

The results demonstrate that these two fragments $A_{25 G 11}$ and $B_{25 G 11}$ were noncontiguous and were separated by a distance of approximately $60 \mathrm{~kb}$ on the chromosome of $109 \mathrm{cS}$. The $60 \mathrm{~kb}$ interval interestingly coincides with the size difference between the integration generated $195 \mathrm{~kb} A p a$ I fragment in 25G11 and the $135 \mathrm{~kb} A p a$ I fragment of $109 \mathrm{cS}$ (Fig. 2). Further, the two original fragments in $109 \mathrm{cS}$ were rearranged and situated with the same orientation at both ends of the integrated vector on the chromosome of 25G11. Therefore, we propose that the $60 \mathrm{~kb}$ region between the two fragments on the chromosome from $109 \mathrm{cS}$ was duplicated entirely on the 25G11 chromosome (Fig. 3, line 5).

\section{Discussion}

In our previous two approaches ${ }^{3,4)}$ in which we performed random mutageneses of $S$. mutans with the pVA891 integration vector, we obtained not only transformants insertionally mutagenized by a typical Compbell-like mechanism but also found several deletion mutants. Deletions were detected in a region flanking the integrated vector in all cases analyzed and the genes were identified in the deleted regions. In addition, we recently carried out another mutagenesis using the same method, and obtained many mutants which could not be explained solely by a typical Campbell-like mechanism. If pVA891 was inserted by a simple Campbell-like mechanism into $S$. mutans strain $109 \mathrm{cS}$ (Fig. 4), the results of mini-gel Southern hybridization analysis (Fig. 1) would not be compatible with such a mechanism, since: (i ) A positive band of size $P$ probed with the fragment $A_{25 G 11}$ should not appear in mutant $25 \mathrm{G} 11$ following EcoR I digestion. (ii) A positive band of size $\mathrm{P}$ probed with the fragment $B_{25 G 11}$ should also not be present in this mutant. (iii) A positive band of size $\mathrm{P}$ in strain $109 \mathrm{cS}$ should be detected when probed with either fragment $A_{25 G 11}$ or $B_{25 G 11}$. (iv) Duplicated positive bands should not appear in 25G11 when probed with either fragment $\mathrm{A}_{25 \mathrm{G} 11}$ or $\mathrm{B}_{25 \mathrm{G} 11}$ (only size $\mathrm{A}$ or $\mathrm{B}$ band should appear in the lane 25G11). (v) We should have been able to detect a direct repeat sequence at both ends of integrated pVA891 on the chromosome of 25G11. Therefore, the mutant $25 \mathrm{G} 11$ cannot result from a typical Campbell-like integration mutant, although pVA891 was actually inserted into the chromosome of $25 \mathrm{G} 11$.

These contradictions were resolved following the analysis of CHEF gel blots. Mapping of both fragments $A_{25 G 11}$ and $B_{25 G 11}$ was successfully performed by introducing $A p a \mathrm{I}$ site with the integration plasmid into $109 \mathrm{cS}$, since targeted insertion occurs with the plasmid containing a specific host fragment ${ }^{2}$.

Mutant 25G11 was not a typical Campbell-like integration mutant but was probably a duplication mutant as shown in Figure 3. Although there is no evidence that the region between fragments $A_{25 G 11}$ and $B_{25 G 11}$ was actually duplicated, we suggest a likely mechanism for this type of duplication (Fig. 5). If more than two vectors are integrated into various sites of the host chromosome with the same orientation, this would result in the placement of multiple direct repeating-units (Indeed, we have observed multiple pVA891 integrations). An unequal cross-over ${ }^{10)}$ 


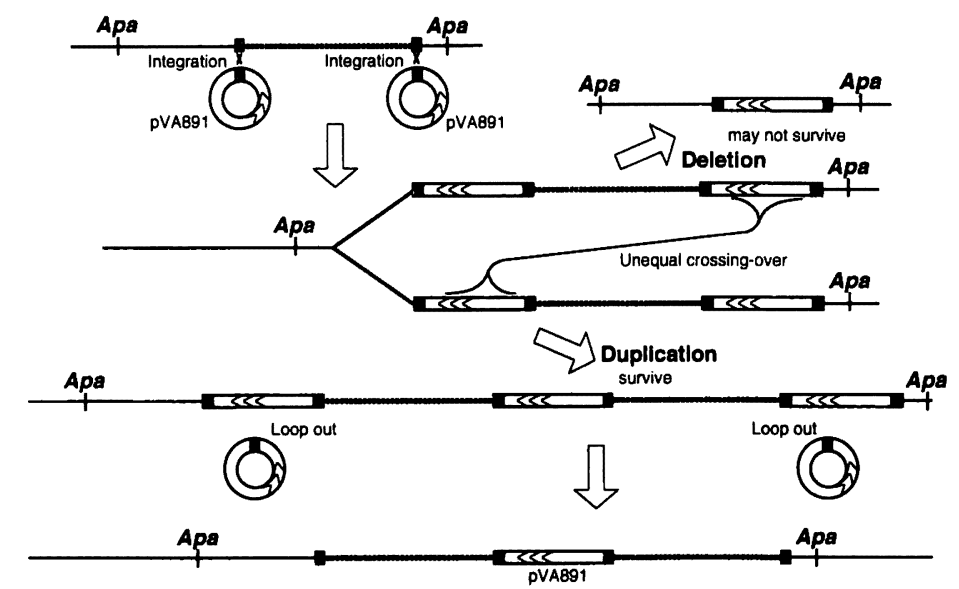

Fig. 5 Schematic illustrations of a suggested mechanism for the generation of merodiploid mutant $25 \mathrm{G} 11$.

Open boxes and circles represent the integrational vector pVA891. Triple arrow heads depicted in the boxes and circles indicates their orientation. Closed and striped boxes represent tandem repeating units generated by multiple Campbell-like integration events. Broken thick lines represent duplicated chromosomal regions. between these direct repeats during chromosomal replication could result in a duplication or deletion of the fragment between the direct repeats in each of the two progenies. Since tandem duplications generally cause no loss of function ${ }^{10}$, the duplication progeny can readily survive. In contrast, the deleted progeny cannot survive if an essential gene(s) was lost. Such a mechanism could explain the data obtained in the present study. Specifically, the reason why we could not observe the direct repeat sequences adjacent to the vector generated by a Campbell-type mechanism is illustrated in Figure 5 by unequal crossing-over during replication followed by loop out. Transformants were screened for erythromycin resistance as an initial step and then selected for the glucan-aggregation defective phenotype. Therefore, mutants were selected to harbor at least one $\mathrm{Em}^{\mathrm{r}}$ gene. However, erythromycin will not serve as a selective pressure for detecting the presence of additional $\mathrm{Em}^{\mathrm{r}}$ genes. In the absence of additional selective pressure, multiple $\mathrm{Em}^{\mathrm{r}}$ genes could be spontaneously excised (looped out) following homologous recombination. Therefore, most mutants other than 25G11 were not generated independent of a Campbell-type mechanism but appeared to be generated by a Campbell-type integration followed by unequal crossing-over events during chromosomal replication.

Why did we obtain so many such duplication mutants but very few typical Campbell-type mutants? It likely depends on the selection system that we employed and may also be influenced by the strain used. We chose strain $109 \mathrm{cS}$ having a relatively high transformation efficiency in order to obtain as many mutants as possible following random mutagenesis. Acinetobacter calcoaceticus competent cells were reported to take up large amounts of DNA ${ }^{11}$. Integration of the internalized DNA competes with degradation. S. mutans competent cells are also likely to take up multiple DNA molecules. We actually detected a mutant in which multiple pVA891 sequences were detected. Yamashita ${ }^{12)}$ et al. observed with $S$. mutans strain $\mathrm{Xc}^{13)}$ having a high transformation efficiency that a recombination-mediated chromosomal segment remained intact following random mutagenesis with an integration plasmid. As described above, we screened mutants exhibiting a phenotype of defective aggregation with glucan. We identified a $g b p C$ gene involving this phenotype by this strategy. GbpC expression appears to be controlled by a complex regulatory mechanism which suggests that multiple factors may be involved in regulation. The $g b p C$ gene could be regulated by repressive factors rather than by inductive regulators. Therefore, we may have obtained more duplication mutants than Campbelllike insertion mutants when selecting for the defective aggregation phenotype.

In mutant $25 \mathrm{G} 11$, the position of the two fragments $A_{25 G 11}$ and $B_{25 G 11}$ around the inserted pVA891 region, were reversed relative to their original positions in $109 \mathrm{cS}$. In other words, these two fragments aligned tail-to-tail at both ends of the integrated pVA891 sequence (Fig. 3) in contrast to a head-to-head 
arrangement in $109 \mathrm{cS}$. A linear DNA molecule aligned as a central nonhomologous sequence flanked on both sides with two homologous fragments which were reversed relative to their original positions reported to be able to integrate into the chromosome, resulting in a duplication of the chromosomal region between the two homologous fragments of the original positions (merodiploidy) ${ }^{10,14,15}$. The alignment of the region around the pVA891 sequence in 25G11 (fragment $A_{25 G 11}-p V A 891-$ fragment $B_{25 G 11}$ ) would have such a structure. This several $\mathrm{kb}$ segment transformed $S$. mutans $109 \mathrm{cS}$, and generated the $60 \mathrm{~kb}$ merodiploid mutants carrying the same chromosomal arrangement as $25 \mathrm{G} 11$. We confirmed this in all 12 mutants that were analyzed. We observed about 300 $\mathrm{kb}$ duplication in one mutant. There have been many reports that strains harboring duplications of more than $20 \%$ of the chromosome were generated by this type of DNA structures ${ }^{10)}$. This type of DNA molecule could be a useful tool to analyze the physiological function of genes. We are currently attempting to construct merodiploid mutants containing specifically duplicated regions of the chromosome and will determine whether or not the mutants exhibit glucandependent aggregation. This approach is currently in progress and will hopefully identify specific gene(s) responsible for this phenotype.

\section{Acknowledgements}

We thank H.K. Kuramitsu (State University of New York at Buffalo) for his critical reading of the manuscript and thank Y. Yamashita (Kyushu University, School of Dentistry) for his helpful comments.

This investigation was supported in part by a Grant from The Hamaguchi Foundation for the Advancement of Biochemistry to Y.S., the Oral Health Science Center Grant 961A03 from Tokyo Dental College, and by Grants-in-Aid for Scientific Research (09671869 to Y.S.) from the Research Fund of the Japanese Ministry of Education, Science, and Culture.

\section{References}

1) Niaudet, B., Goze, A. and Ehrlich, S. D. : Insertional mutagenesis in Bacillus subtilis : mechanism and use in gene cloning. Gene $19: 277-284,1982$.

2) Dowds, B. C. A., O'kane, C., Gormley, E., McConnel, D. J. and Devine, K. M. : Integrating plasmids in the genetic engineering of bacilli In : Recombinant DNA and bacterial fermentation. (Thomson, J. A.), pp. 137-156, CRC Press. Boca Raton, Florida, 1988.

3) Sato, Y., Yamamoto, Y., Kizaki, H. and Kuramitsu, H. K. : Cloning of the phospho- $\beta$-galactosidase gene in Escherichia coli from lactose-negative mutants of Streptococcus mutans isolated following random mutagenesis with plasmid pVA891 clone banks. FEMS Microbiology Letters 91 : 219-224, 1992.

4) Yamamoto, Y., Sato, Y., Takahashi-Abbe, S., Abbe, K., Yamada, T. and Kizaki, H. : Cloning and sequence analysis of the $p f 1$ gene encoding pyruvate formate-lyase from Streptococcus mutans. Infection and Immunity $64: 385-391,1996$.

5) Sato, Y., Yamamoto, Y. and Kizaki, H. : Cloning and sequence analysis of the $g b p C$ gene encoding a novel glucan-binding protein of Streptococcus mutans. Infection and Immunity $65: 668-675,1997$.

6) Nakayama, K., Kadowaki, T., Okamoto, K. and Yamamoto, K. : Construction and characterization of arginine-specific cysteine proteinase (Arg-gingipain)-deficient mutants of Porphyromonas gingivalis. Evidence for significant contribution of Arg-gingipain to virulence. J. Biological Chemistry 270 : 23619-23626, 1995.

7) Dickinson, J. H., Grant, K. A. and Park, S. F. : Targeted and random mutagenesis of the Campylobacter coli chromosome with integrational plasmid vectors. Current Microbiology 31: 92-96, 1995.

8) Okahashi, N., Sasakawa, C., Okada, N., Yamada, M., Yoshikawa, M., Tokuda, M., Takahashi, I. and Koga, T. : Construction of a Not I restriction map of the Streptococcus mutans genome. J. General Microbiology 136 : 2217-2223, 1990.

9) Sambrook, J., Fritch, E.F. and Maniatis, T. : Molecular Cloning : A Laboratory Manual/Second Edition, pp. 1.74-1.84, Cold Spring Harbor Laboratory, Cold Spring Harbor, New York, 1989.

10) Anderson, R. P. and Roth, J. R. : Tandem genetic duplications in phage and bacteria. Annual Reviews of Microbiology 64 : 473-505, 1977.

11) Palmen, R. and Hellingwerf, K. J. : Uptake and processing of DNA by Acinetobacter calcoaceticus -a review. Gene 192: 179-190, 1997. 
12) Yamashita, Y. : personal communication, 1997.

13) Tsukioka, Y., Yamashita, Y., Oho, T., Nakano, Y. and Koga, T.: Biological function of the dTDPrhamnose synthesis pathway in Streptococcus mutans. J. Bacteriology 179 : 1126-1134, 1997.

14) Niaudet, B., Janniere, L. and Ehrlich, S. D. : Integration of linear, heterologous DNA molecules into the Bacillus subtilis chromosome: mechanism and use in induction of predictable rearrangements. J. Bacteriology 163: 111-120, 1985.

15) Young, M. and Hranueli, D. : Chromosomal gene amplification in Gram-positive bacteria In : Recombinant DNA and bacterial fermentation. (Thomson, J. A.), pp. 157-200, CRC Press. Boca Raton, Florida, 1988. 